\title{
How Fairness Principles in the Climate Debate Relate to Theories of Distributive Justice
}

\author{
Marc David Davidson
}

check for updates

Citation: Davidson, M.D. How Fairness Principles in the Climate Debate Relate to Theories of Distributive Justice. Sustainability 2021, 13, 7302. https://doi.org/ $10.3390 /$ su13137302

Received: 2 June 2021

Accepted: 28 June 2021

Published: 29 June 2021

Publisher's Note: MDPI stays neutral with regard to jurisdictional claims in published maps and institutional affiliations.

Copyright: (C) 2021 by the author. Licensee MDPI, Basel, Switzerland. This article is an open access article distributed under the terms and conditions of the Creative Commons Attribution (CC BY) license (https:/ / creativecommons.org/licenses/by/ $4.0 /)$.
Department of Ethics and Political Philosophy, Faculty of Philosophy, Theology and Religious Studies, Radboud University, 6525 HT Nijmegen, The Netherlands; marc.davidson@ru.nl

\begin{abstract}
A central question in international climate policy making is how to distribute the burdens of keeping global average temperature increase to well below $2{ }^{\circ} \mathrm{C}$ above pre-industrial levels. In particular, there are four distributional issues: how to allocate the total amount of greenhouse gases that can still be emitted, who should bear the costs of mitigation, who should bear the costs of adaptation to unavoidable climate change, and who should bear the costs of residual climate damage. Regarding these distributional issues the academic literature offers a plethora of fairness principles, such as 'polluter pays', 'beneficiary pays', 'equal per capita rights', 'grandfathering', 'ability to pay', 'historical responsibility' and 'cost effectiveness'. Remarkably, there is a theoretical gap between these principles and the central theories of distributive justice in moral and political philosophy. As a consequence, it is unclear how these principles are related, whether they can be combined or are mutually exclusive, and what the fundamental underlying values are. This paper aims to elucidate that debate. Understanding the different underlying values may facilitate bridge-building and movement in negotiation positions.
\end{abstract}

Keywords: carbon budget; distributive justice; climate negotiations; mitigation; fairness; burdensharing; CBDR

\section{Introduction}

The ultimate aim of the 1992 United Nations Framework Convention on Climate Change (UNFCCC) is to stabilize greenhouse gas concentrations at a level that would prevent dangerous anthropogenic (human-induced) interference with the climate system. On 12 December 2015, at the 21st Conference of the Parties to the UNFCCC in Paris, representatives of 196 state parties agreed to keep "the increase in the global average temperature to well below $2{ }^{\circ} \mathrm{C}$ above pre-industrial levels and to pursue efforts to limit the temperature increase to $1.5^{\circ} \mathrm{C}$ above pre-industrial levels" [1].

Both the UNFCCC and the Paris Agreement imply that humanity can only emit a limited amount of greenhouse gases. According to the Intergovernmental Panel on Climate Change [2], we have a $66 \%$ chance of limiting the temperature rise to $2{ }^{\circ} \mathrm{C}$ above preindustrial levels if we emit less than 2900 gigatonnes (GT) of $\mathrm{CO}_{2}$ into the atmosphere (after excluding non- $\mathrm{CO}_{2}$ forcing). Between 1870 and 2011 we had already emitted about 1900 GT, implying that we are left with a 'carbon budget' of less than 1000 GT for the rest of this century. To keep the $2{ }^{\circ} \mathrm{C}$ target in sight, annual global greenhouse gas emissions need to be reduced from the present $50 \mathrm{Gt} \mathrm{CO}_{2}$-equivalent to $41 \mathrm{Gt} \mathrm{CO}_{2}$-eq. in 2030 [3].

World leaders labeled the Paris Agreement a breakthrough and a great success. For the first time, virtually all countries, both industrialized and developing, pledged to curb their national greenhouse gas emissions. This unanimity came at a high price, however. The Paris Agreement allowed each country to propose voluntary Intended Nationally Determined Contributions (INDCs) [4]. Given the nature of collective action problems [5], few scientists were surprised that the sum of all voluntary INDCs, even if all pledges are honored, will be insufficient to limit global temperature rise to $2{ }^{\circ} \mathrm{C}[3,6]$. 
To ensure total emissions do indeed remain within safe limits, the global carbon budget needs to be allocated among the different countries with accompanying sanctions for non-compliance. Without such "mutual coercion, mutually agreed upon", as Garret Hardin [7] emphasized in The Tragedy of the Commons, it remains individually rational to free ride on the efforts of other countries. The agreement signed in Montreal in 1987 to protect the ozone layer shows that such a binding global agreement supported by sanctions is both possible and effective [8]. Elinor Ostrom [9] demonstrated that collective-action problems occurring on a small, local scale, where there is direct interaction among participants, can be solved by mutual consultation. Climate change is far from being a local or small-scale issue, however.

International allocation of the carbon budget is needed to establish a level playing field for internationally operating companies, moreover. Without a uniform global carbon price, established by flexible economic instruments such as internationally tradable emission rights or uniform carbon taxes, 'carbon leakage' will occur [10]: businesses will either transfer production to other countries or lose competition to businesses in countries with laxer emission constraints. This means that countries willing to take the lead are restricted in how far ahead of the pack they can go without their industry facing too much competitive disadvantage.

The economic stakes involved in international allocation of the carbon budget are enormous. If we assume a carbon price in the order of US $\$ 50-100 / \mathrm{tCO}_{2}$ by 2030 [11] and the aforementioned annual carbon budget of $41 \mathrm{Gt} \mathrm{CO}_{2}$, the market value of that budget in 2030 would be in the order of two to four trillion US dollars. With an estimated global GDP in 2030 of over US \$100 trillion, the value of the annual carbon budget thus amounts to several percent of global GDP. Given the enormity of the implied distributive issue, it is understandable that government leaders have to date avoided negotiations on international allocation of the carbon budget. However, the failure of voluntary agreements to prevent dangerous interference with the climate system means these negotiations can no longer be avoided.

There are other substantial distributional issues, too. Hof et al. [12] estimate the total mitigation costs of reaching a global annual emission level of $42 \mathrm{GtCO}_{2}$-eq in 2030 at between $0.31 \%$ and $0.64 \%$ of global GDP, comparable with the (median) estimate of about $0.6 \%$ reported by the IPCC [13]. The reinsurance provider Munich Re [14] estimates global losses in 2020 due to natural disasters at US $\$ 210$ billion, i.e., a fraction of a percent of global GDP as well, in line with expected climate damage if global temperature rise remains well below $2{ }^{\circ} \mathrm{C}$ above pre-industrial levels [15]. Moreover, there will be costs of adaptation to reduce the residual climate damage occurring even if the Paris Agreement targets are reached.

The objective of this article is to elucidate the debate on fair allocation of the carbon budget, climate mitigation costs, adaptation costs and the residual climate damage occurring despite all mitigation and adaptation. The academic literature offers a plethora of fairness principles, such as 'polluter pays', 'beneficiary pays', 'equal per capita rights', 'grandfathering', 'ability to pay', 'historical responsibility' and 'cost effectiveness' (see, e.g., [16-24]. Remarkably, there is a theoretical gap between these principles and the central theories of distributive justice in moral and political philosophy. As a consequence, it is unclear how these principles are related, whether they can be combined or are mutually exclusive, and what the fundamental underlying values are. The hope is that a deeper understanding of the aforementioned principles will facilitate negotiations as well as the academic debate. A second aim is to explain the values underlying opposing positions in the climate negotiations, such as the principle of common but differentiated responsibilities (CBDR) in the UNFCCC and the opposition by the United States, in particular.

This article focuses explicitly on the distributional issues involved in achieving the Paris Agreement targets. This means many aspects of climate justice will be left undiscussed, such as procedural justice-concerned with such questions as whether all those affected by decisions have a voice and representation in the process-and whether these 
processes are transparent. Questions regarding justice towards future generations as well as non-human life are likewise neglected, since these questions precede the determination of carbon budgets and emission reduction goals.

In this article it is assumed that the aforementioned fairness principles, such as 'polluter pays', can be explained by relating them to three main theories of distributive justice only: libertarianism, liberal-egalitarianism and utilitarianism. In anticipation of later, more detailed discussions, a very crude distinction between these three theories can be made as follows. If we make the deontological distinction between perfect duties not to harm others in bodily integrity and personal property, and imperfect duties to aid others in need [25], libertarians believe the sole role of governments is to make people conform to perfect duties, while liberal-egalitarians also see a role for governments in coordinating the collective fulfillment of imperfect duties. Utilitarianism denies the existence of either kind of duty and measures the goodness of government policy only by its effectiveness in increasing the sum total of utility, happiness or wellbeing of all concerned.

The setup of this article is as follows. For each theory of distributive justice, first its core ideas are summarized, after which it is explained which distribution principles follow for the climate debate. There then follows a discussion of how these principles relate to the fairness principles expressed in the UNFCCC. The article ends with a discussion and conclusion.

\section{Libertarianism}

Libertarianism has its origins in John Locke's Two Treatises of Government [26]. As its centre is the simple idea that people should be free from constraints or coercion by others in shaping their own lives. This central idea is most easily understood with reference to the moral theory of deontology [27] (pp. 30-31), according to which we have perfect duties to refrain from acts such as harming others in bodily integrity and personal property, and imperfect duties to perform certain acts such as helping others in times of need. However, while the perfect duties are mirrored by corresponding negative rights, i.e., rights against other people that they do not perform certain acts, the imperfect duties are not mirrored by corresponding positive rights, i.e., rights against other people that they are obliged to help you (for the distinction between negative and positive rights, see $[28,29])$. The reason for this is that perfect duties trump imperfect duties in the case of conflict. If you would be entitled to my help, even if I would not want to help, that would imply treating me as a means instead of an end-in-itself.

According to libertarians, the primacy of negative rights strongly limits the justified influence of governments on our lives and the scope for governments to redistribute wealth. People should not be forced by society against their will to contribute, for example, to aiding the worst-off in society (as argued for by liberal-egalitarianism) or improving the greater good (as argued for by utilitarianism). In fact, libertarians compare involuntary taxation to theft or forced labor. Libertarians do not deny duties to help others in need, but they reject the right of governments to enforce such help. Since libertarians consider only voluntary transfer of private property to others legitimate, either in exchange or as a gift, libertarianism is highly conducive to capitalism and the free-market economy. As far as libertarians see a role for a government, it is to protect citizens' negative rights by means of the police and the legal system. The variety of libertarianism that does not even accept such a 'night-watchman state', for example because even such a pruned-back government still requires some taxation to fund it, becomes anarchism.

Although libertarianism is more or less clear about individual rights to bodily integrity, private property and what is to be deemed legitimate exchange of that property, it leaves far greater scope for discussing the legitimacy of turning initially unowned natural resources into private property [30]. A central controversy is whether there are limitations to the extent to which one may appropriate natural resources that have not yet been appropriated by others and, if such limitations indeed exist, how these should be formulated. There are two paradigmatic positions. According to right-libertarianism, people are entitled to 
unlimited appropriation of previously unowned natural resources on the basis of first come, first served (see, e.g., $[27,29,31,32]$ ), although appropriation may not always imply absolute ownership [27,33,34]. According to left-libertarianism, natural resources are by definition not the product of anyone's efforts or labor, and therefore no one person is more entitled to them than another. If we are all entitled to the maximum liberty to give shape to our own lives, that is still compatible with equal liberty for all, this must then imply equal per capita entitlements to natural resources (see, e.g., [35-37]).

\subsection{Right-Libertarianism: Carbon Budget and Grandfathering}

Since no-one created the 'carbon budget' - the total amount of greenhouse gases that can be emitted before anthropogenic interference with the climate system is deemed to become dangerous - this budget can be considered a scarce natural resource similar to fossil fuels or land surface. The right-libertarian principle of first come, first served therefore implies not only that past emissions by the industrialized countries have been rightful, but also that present emissions justify claims for future emissions, as expectations regarding future use have been built upon earlier activities that need to be honored in the future. Countries emitting a certain share of global emissions at the time reduction targets are set are thus deemed to have the right to retain the same share of emissions subsequently. Under this arrangement, generally referred to as grandfathering, if all countries must reduce their national emissions, they need to do so by the same percentage relative to a particular base year.

Right-libertarianism and its resultant principle of grandfathering are unpopular views among environmental philosophers and-if mentioned at all—are often rejected as obviously unfair (see, e.g., [38-41] (p. 128); but see [42]). The two chapters on justice in the IPCC's Fifth Assessment Report [20,21] do not mention grandfathering as a distributional justice principle at all. This is remarkable, given that both national and international legal systems pertaining to natural resources are largely based on it. The right-libertarian morality of first come, first served is consistent with the concept of state sovereignty, for example: according to Principle 21 of the Declaration of the United Nations Conference on the Human Environment (UNCHE 1972): "States have, in accordance with the Charter of the United Nations and the principles of international law, the sovereign right to exploit their own resources pursuant to their own environmental and developmental policies, ... " It is therefore widely accepted that fossil fuel reserves and other natural resources belong to the countries where they are found. In other words, if grandfathering entails injustice to developing countries by hampering their development, there is no fundamental difference with the situation that developing countries lacking fossil fuel reserves are disadvantaged relative to countries that do. Present international law contains no provisions for international redistribution of such natural resources apart from market exchange. A right-libertarian approach was adopted, moreover, on inception of the European Emissions Trading Scheme in 2005, under which major industrial facilities and power generators require tradable allowances for their carbon emissions. Initially, the available allowances were allocated free of charge to EU Member States on the basis of their historical emissions in a reference period prior to the scheme's introduction, i.e., on a grandfathering basis. See for other examples of grandfathering the U.S. Clean Air Act [43], U.S. land use law, international regulatory law and other legal realms [44]. It should be noted, though, that the fact that the international world order is largely organized along right-libertarian lines in itself provides no moral justification that it ought to be.

\subsection{Left-Libertarianism: Carbon Budget and Equal per Capita Rights}

Although the international legal order is based largely on a right-libertarian morality, it is a left-libertarian morality that underlies the 'Common Heritage of Humankind principle' applied to the deep-sea bed, Antarctica and outer space, no part of which may be claimed by any country, company or individual on account of getting there first [45]. 
Applied to the global carbon budget, left-libertarianism implies that each of the world's inhabitants has an equal right to emit greenhouse gases. This would mean allocating the global carbon budget to individual countries as tradable emission rights on the basis of population size, or introducing a uniform global carbon tax, the revenues of which are distributed to countries according to population size. The principle of equal per capita rights to the carbon budget has been advocated by numerous authors (see, e.g., [46-50]), without it being explicitly connected to theories of distributive justice.

Equal per capita rights to the global carbon budget would result in substantial financial flows from developed to developing countries. Given the strong correlation between greenhouse gas emissions and wealth, developed countries would need a greater share of the carbon budget and would have to financially compensate developing countries for using less. As mentioned earlier, once strict targets are set, the economic value of a global carbon budget will be trillions of dollars per year. The United States, for example, whose share of global GDP and annual carbon emissions is about 15\% while its share in world population is about $4 \%$, would have to buy around $10 \%$ of the world's carbon budget on the global carbon market. This would imply the transfer of hundreds of billions of dollars a year, primarily to developing countries. India, whose share of global GDP and annual carbon emissions is about $8 \%$ while its share in world population is around $18 \%$, could sell $10 \%$ of the global carbon budget, receiving hundreds of billions of dollars a year, primarily from developed countries.

\subsection{Left-Libertarianism: Carbon Budget and Historical Responsibility}

Despite the substantial financial transfers from developed to developing countries that would result if all people would receive an equal per capita share of the carbon budget, there is a rationale for even larger transfers. In the examples given in the previous section, past emissions were neglected. There are reasons, however, to apply the principle of equal per capita rights retroactively, i.e., taking historical emissions into due account. Under this arrangement, a country emitting more than its fair share in the past would be entitled to a smaller share in the future [51,52]. While historical emissions increase future entitlements under right-libertarianism, then, under left-libertarianism they diminish those entitlements. This approach certainly has intuitive appeal: that there is only a limited carbon budget left to distribute is due to past emissions. If for whatever reason I arrive late at dinner and my four friends have already eaten four of the five available pizzas, then it does not seem fair to give me only a fifth of the one remaining pizza. In fact, this was the approach in the so-called 'Brazilian Proposal' presented by the Brazilian government in the run-up to the third Conference of the Parties (COP 3) to the UNFCCC in Kyoto, Japan, in 1997. According to this proposal, the emission reductions required of countries, and thus their allotted share of the carbon budget, should be based on their relative responsibility for global temperature rise [53].

Taking historical emissions into account raises several theoretical and practical questions, however. First, a large proportion of past emissions occurred before the polluters could reasonably have known about the risk of climate change. Is it fair to hold polluters responsible for those emissions [46]? It is generally assumed that we cannot be blamed for acts whose consequences we could not reasonably foresee. A distinction should be made, however, between action-responsibility and outcome-responsibility [54,55]. Actionresponsibility determines whether an act should be regarded as blameworthy and/or deserving punishment, while outcome-responsibility determines whether a person is liable to pay compensatory damages. Libertarianism takes the position that action-responsibility is irrelevant for outcome-responsibility: individuals are fully responsible for the harmful outcomes of their actions, and consequently ignorance does not remove the obligation to compensate. See for an application of this distinction to the case of climate change [16,51]; for doubts about this distinction see $[56,57]$.

Second, a large share of emissions are due to people who are dead. Do the present inhabitants of industrialized countries have an 'ecological debt' because of their ancestors' 
deeds $[47,58]$ ? Normally, we do not entertain the belief that people can be blamed for the acts of other people. We do not go to jail for crimes committed by our parents, for example. A first possible solution is to hold countries responsible for past emissions rather than individuals, since countries generally have a much longer lifespan than their citizens. This approach raises many questions, however. Are countries moral subjects? How can collectives, such as countries, have mutual obligations if these obligations cannot be based upon obligations by the individuals making up those collectives [59]. After all, the collective obligation must be distributed over its members, which once again reintroduces the question of which principles to base such distribution on. Can individual people have an obligation to bear the consequences emerging from collective decisions in which they did not participate [60]? Libertarians, in particular, will be reluctant to accept such responsibilities. What to do about countries whose borders have changed or which have ceased to exist altogether [61,62]? To what extent is an immigrant responsible for the past emissions of her new home country? In spite of these philosophical puzzles, it should be noted that the international community seems to have little trouble dealing with financial debts between countries, which obviously raise comparable issues. It is generally assumed that citizenship is a package deal: as a citizen, we accept both the benefits and the duties resulting from being a member of a particular society.

An alternative approach is the so-called Beneficiary Pays Principle $[16,40,51,60,63,64]$ (p. 536). Although previous generations may have passed away, present generations still reap the benefits of past industrial activities involving the burning of fossil fuels. Although we, the heirs of the legacy of previous generations, are not to blame for past emissions, we hold duties of 'remedial responsibility' [65] (pp. 97-107). Consider, for example, inheriting a painting from a grandparent that turns out to be stolen. Even if we are not to blame for the theft, we are under an obligation to return the painting to its rightful owner or their heirs. Problematic, however, is that the benefits present individuals are presumed to reap from the burning of fossil fuels in the past are not as clear as the enjoyment of stolen goods such as paintings (see also [22]). It is often impossible to trace the origins of present entitlements. With somewhat more certainty we can determine whether countries benefited from their past emissions. If we are concerned with the responsibilities of countries rather than individuals, though, we do not need the beneficiary pays principle at all.

\subsection{Libertarianism: Mitigation Costs and the Polluter Pays Principle}

Once the global carbon budget is allocated, either on the basis of grandfathering or equally per capita, countries bear their own costs of mitigation so as to stay within their portion of the budget. Libertarianism provides no justification for the burden of mitigation being shouldered according to varying capacity, level of economic development or ability to pay. Libertarianism is thus compatible with the Polluter Pays Principle [66], adopted by the OECD on 26 May 1972 as an economic principle for allocating the costs of pollution control and included as Principle 16 in the 1992 Rio Declaration on Environment and Development.

\subsection{Libertarianism: Adaptation Costs and Climate Damage}

According to the IPCC, human influence on the climate system is clear, and recent climate changes have had widespread effects on human and natural systems [2]. Even if the Paris climate targets are achieved, sea levels will rise, biological diversity will be lost and risks to health, livelihoods, food security, water supply, human security and economic growth will increase [67]. Societies can go some way to alleviating this climate damage by means of adaptation: by building (higher) dikes, adjusting water management regimes, developing new heat stress-resistant agricultural crops or even migration. In other words, even if the world stays within the carbon budget in accordance with the targets of the Paris Agreement, countries will face the costs of adaptation and of climate damage.

Under libertarianism, people have a duty not to cause physical harm or damage to the property of third parties and the perpetrator is therefore responsible for full compensation 
if damage does occur [27] (pp. 79-80). The same applies to the costs that victims need to incur to minimize damage, i.e., adaptation costs. This requirement to compensate damage and adaptation costs is often also called the polluter pays principle, although this principle originally only referred to the responsibility to bear mitigation costs [68].

In practice, however, recovering the costs of adaptation and climate damage from those causally responsible is problematic. First, it is still impossible to unambiguously assign local climate-related damage, due to a hurricane or heat wave, for example, to human influence. The IPCC's assessment that humans are already changing the climate is based on statistical analysis on a global scale and measurements over many years. Second, current climate change is the result not only of present emissions, but also those in the (distant) past. There is a time lag of a decade before present emissions lead to climate change [69], while the effects will continue for centuries to millennia [70]. Who, then, should currently be held liable for compensation? The same issues arise here as with historical responsibility for expending the carbon budget (see the previous Section 2.3). It should be noted here that, given the time lag between emissions and damage, it is not self-evident to use the revenues of carbon taxes and tradable emission rights for compensating current victims. Instead, revenues from income tax or corporate tax are more appropriate. If damage and adaptation costs cannot be recovered from those causally responsible, states affected by climate change will have to bear their own costs. Libertarianism rejects the notion of cost distribution according to the principle that the strongest shoulders should bear the heaviest burden, for example.

\section{Liberal-Egalitarianism}

Like libertarianism, liberal-egalitarianism is to a large extent based upon deontological principles. However, while libertarians consider there to be no justification for governments improving the position of the less advantaged by means of transfers, liberal-egalitarians do. Liberal-egalitarians agree with libertarians that people should have an equal right to the most extensive overall system of basic liberties compatible with a similar system of liberty for all, such as the political liberty to vote and run for office, freedom of speech and assembly, liberty of conscience, freedom from arbitrary arrest and freedom of personal property [71]. For liberal-egalitarians, however, the freedom of personal property is less sacred than for libertarians. How do liberal-egalitarians justify taxation? How can taxation be reconciled with the deontological principle never to treat people merely as means, but always at the same time as ends-in-themselves?

A first argument is that private property is generally not the product of one's individual doings but the product of social cooperation. Without the efforts of other members of the community, people would be unable to earn any substantial income. It may be doubted, therefore, whether it makes sense to speak of property rights independent of taxation, as if taxation violates the perfect duty to respect people's (pre-existing) personal property $[72,73]$. After all, the same property rights would not have existed without a society in which taxes are raised. It is thanks to taxation and the services provided by governments, ranging from law and order to social security, that property is created.

A second argument is that people differ in their capacity to shape their own lives, leading to an unfair playing field. People are born, for example, with different natural advantages (talents) or disadvantages (disabilities) that are not their own doing and beyond their own choice, or people are advantaged or disadvantaged by being born into a social setting offering more or less opportunities for development. Liberal-egalitarians therefore consider it less evident that people are fully 'entitled' to their property and income.

To contemplate a 'fair' organization of society, John Rawls [71] asks us to imagine ourselves under a 'veil of ignorance', behind which one would not know one's position in society, abilities and the like. Since one could end up in the worst position, Rawls believes it is rational to 'play safe' and optimize the position of this worst position. This could be achieved, among other means, by taxation and social security. Rawls does not favor complete redistribution of wealth, however, since this would remove an important 
incentive for generating wealth. For many people, after all, an important reason to generate wealth is to improve their own lives. A fully egalitarian distribution of wealth could therefore leave the least advantaged in worser off than if some inequalities are allowed. Rawls therefore proposes that social and economic inequalities are to be arranged such that they are to the greatest benefit of the least advantaged. This is called the difference principle.

According to Ronald Dworkin [74], a just society compensates people for brute luck, i.e., uncontrollable circumstances that hamper one's options for shaping one's life, such as handicaps and other natural misfortunes. Natural endowments of intelligence and talent are after all morally arbitrary. Why should you be 'entitled' to far more wealth than others simply because you were born with certain talents? So where left-libertarians see reason to redistribute the value of external natural resources because they are not the product of your own doing, 'luck-egalitarians' such as Dworkin see reason to redistribute the value of internal natural resources as well. According to Dworkin, though, a just society should not compensate option luck, i.e., (mis)fortune that results from one's own choices. People are responsible for the life choices they make. If I gamble and lose, there is no reason for society to compensate me for my losses. According to Dworkin, a fair distribution of resources should therefore be ambition-sensitive, but endowment-insensitive. Where Rawls believes inequality is justified only in as far as it benefits the least advantaged, Dworkin thus believes inequalities can be justified if they result from different life choices.

It should be noted that liberal-egalitarianism does not merely advocate the compensation of disadvantages through redistribution and the 'welfare state', i.e., subsequent fixing of the problem, but also aims to remove unfair disadvantages beforehand, for example by ensuring that people's opportunities in life are not determined by the social setting into which they are born. Moreover, it should be noted that some authors have argued for complete equality of the overall level of benefits and burdens of each member of society [75], but such strict egalitarianism is a minority view.

\subsection{Nationalism and Cosmopolitanism}

A question for liberal theorists is whether the duty to improve the position of the less advantaged applies globally or only nationally, i.e., only to the members of one's own society. This is the debate between 'cosmopolitans' and 'nationalists' or 'communitarians'. While it is generally recognized that the negative duties of non-interference are not only owed to fellow-countrymen but hold universally, the positive duties of assisting those in need are often justified in relation to (national) cooperative schemes. Rawls himself, for example, believed that the difference principle only applied to citizens within states but not between states [76] (pp. 113-120). Such (re)distributive justice would only apply where there is an ongoing scheme of social cooperation, assumed only to exist within a state, not among citizens in different states (see, e.g., [77] (pp. 390-391)). In the international context, distributive justice would fall back to the principles of libertarianism, perhaps supplemented by certain humanitarian duties to aid the poor (see also [77] (pp. 390391) and [78]). Other authors, such as Beitz [79], Pogge [80,81], Moellendorf [82] and Caney [57], disagree that social cooperation is a necessary condition to justify the difference principle, however, or believe that in our modern 'globalized' world there is sufficient international social cooperation to justify an international difference principle. According to Pogge [80,81], the industrialized world causally contributes, and has contributed, to poverty in the developing countries, implying that helping the poor is not merely a matter of positive duties, but a negative duty borne out of corrective justice.

\subsection{Cosmopolitan Liberal-Egalitarianism: Carbon Budget}

It was argued above that left-libertarianism would recommend an equal per capita allocation of the global carbon budget. Although 'equal per capita' would be compatible with strict egalitarianism [75] as well, the goals of cosmopolitan liberal-egalitarianism are best served by diverting the entire carbon budget to improve the situation of the least advantaged countries, in line with the proposals of cosmopolitan liberal-egalitarians like 
Beitz [79] and Pogge [80,81], as well as by Armstrong [23]. After all, if no-one has any particular entitlement to natural resources, then using the carbon budget to improve the situation of the least advantaged is to be preferred to taxation of the more advantaged, since liberal egalitarianism would prefer to avoid violating private property entitlements. From this perspective, then, either tradable emission rights can be auctioned in their entirety or a globally uniform carbon tax can be introduced. In both cases, the revenues can be used by a central organization such as the United Nations to help countries achieve the Sustainable Development Goals, such as alleviating poverty and hunger. The association of the principle of 'equal per capita' with the political theory of liberal egalitarianism (see, e.g., $[38,83])$ has therefore often been unjustified.

\subsection{Cosmopolitan Liberal-Egalitarianism: Mitigation Costs and Ability to Pay}

Although right- and left-libertarians have been shown to hold different views on how the carbon budget should be allocated, both agree that countries should bear their own cost of staying within their individual budget. There is no justification for governments to help each other shoulder mitigation costs. In contrast to libertarianism, though, cosmopolitan liberal-egalitarian theories see justification for governments reducing the burden of mitigation for other, less advantaged countries. For cosmopolitan liberal-egalitarians, this is a matter of fairness: whether one is more or less able to bear the cost of climate policy depends largely on sheer luck, including one's place of birth. In contrast to libertarianism, liberal-egalitarianism is thus compatible with a principle central to the debate on climate justice and discussions on fair tax systems: the Ability to Pay principle (see, e.g., [16] (p. 537)). In the context of the climate debate, this principle implies that individuals or countries have a responsibility to bear a larger share of the costs of (international) climate policy the wealthier they are, irrespective of the extent to which they have contributed to climate change. In principle, therefore, each country is responsible for its own mitigation costs according to the polluter pays principle, but the mitigation costs of the least advantaged countries are to be shared among countries on the basis of the ability to pay principle. The Ability to Pay principle is not well defined, however. Bearing a 'larger' share of the costs can imply anything between 'marginally more' and 'all'. The Ability to Pay principle can be interpreted as people or countries contributing to mitigation costs either proportionally to (national) income or progressively, meaning that the marginal contribution rises in step with (national) income.

Several authors have proposed putting a lower limit on ability to pay, with those below a certain minimum living standard being relieved of any obligation to contribute to mitigation of climate emissions [16] (p. 541). This can be termed a 'sufficientarian' side-constraint. According to sufficientarianism [84,85], we should strive to ensure that as many people as possible move above the threshold marking the minimum required for a decent (sufficiently good) quality of life. In contrast to liberal-egalitarianism, however, sufficientarianism sees no justification for specific additional duties to further improve people's lives once they are above that threshold.

Finally, it should be observed that liberal-egalitarianism applied to the international climate issue faces the problem of 'local justice' $[56,86]$. In an international world order that is not liberal-egalitarian, the question may be asked why we would apply liberal-egalitarian principles specifically to the distribution of the burdens of climate mitigation. If those in an advantaged position are willing to help those in a less advantaged position, why then divert the available funds to help reduce the costs of climate mitigation in particular? In all likelihood, the same funds could help more people if used to fight poverty across the board, through investments in democracy, health care and education, for example [83,87].

\subsection{Cosmopolitan Liberal-Egalitarianism: Adaptation Costs and Climate Damage}

According to liberal-egalitarianism, just as in the case of libertarianism, those inflicting damage to the health and personal property of third parties have a duty to compensate the victims. The difference with libertarianism, however, is that if damage and adaptation 
costs cannot be recovered from the perpetrators, the costs are to be spread on the basis of the ability to pay principle.

\section{Utilitarianism}

Utilitarianism, originating in the work of Jeremy Bentham [88], is the theory according to which the good act maximizes the happiness or utility of all concerned. Utilitarianism is simultaneously an ethical theory for individual conduct and a political theory, i.e., a recommendation for the organization of society. Although utilitarianism is concerned with neither negative nor positive rights or duties as such, it supports rights to private property and the accompanying rights to freely exchange goods. The free exchange of goods on free markets optimizes the allocation of scarce resources and will thus lead to Pareto optimal social welfare. Utilitarians therefore favor the free market for other reasons than libertarians. Combining the idea that free markets optimize society's wealth with the libertarian argument that free markets and small governments are an expression of individual liberty and strong negative rights leads to the doctrine of neoliberalism as advocated by Friedrich Hayek [89], Ayn Rand [90] and Milton Friedman [91].

Utilitarianism does not aim to maximize wealth, however, but utility. Utilitarianism therefore favors wealth redistribution, not because the less advantaged are entitled to aid, but because of the law of diminishing marginal utility, as already observed by Bentham [92] (pp. 228-229). Redistribution of wealth from the more to the less advantaged will thus increase overall utility. Prioritarianism [93], a variety of utilitarianism, gives even more reason for wealth redistribution to the less advantaged. According to prioritarianism, it is morally better to add a unit of utility for someone with a lower level of wellbeing than for someone with a higher level. Complete redistribution and thus equalization of wealth would be unwise, however, since that would weaken the incentive for individuals to increase their wealth as argued by Rawls [71] in the context of liberal-egalitarianism. At what level of taxation government revenues and thus redistribution are maximized is a matter of empirical calculation.

Utilitarianism does not face the same question as liberal-egalitarianism as to whether the principle should be applied nationally or globally, since the duty to maximize utility does not depend on the nature of social ties. As the utilitarian Peter Singer argued in his influential article Famine, Affluence, and Morality [94] (pp. 231-232): "It makes no moral difference whether the person I can help is a neighbor's child ten yards from me or a Bengali whose name I shall never know, ten thousand miles away." Utilitarian duties to prevent harm and to do good have a global reach, and as long as there are global differences in wealth the wealthier have both the capacity and the obligation to help the poor.

\subsection{Utilitarianism: Carbon Budget}

Since the aim of utilitarianism is to maximize the happiness, utility or wellbeing of all concerned, the first recommendation is to achieve the Paris Agreement targets costeffectively. Cost-effectiveness can be achieved by establishing a globally uniform carbon price through implementation of economic instruments, such as carbon taxes or tradable emission rights. If no international emission trading is allowed, cost-effectiveness requires the carbon budget to be allocated in such a way that all countries have the same marginal mitigation costs. The second recommendation is to use the revenues of these instruments to improve the situation of the least advantaged [95], p. 42 and [96]. Due to the diminishing marginal utility of money, using these revenues for the least advantaged will generally lead to the greatest increase in happiness. See Meyer and Roser [97] for allocation of the carbon budget along prioritarian lines.

\subsection{Utilitarianism: Mitigation, Adaptation and Damage Costs}

Unlike libertarianism and liberal-egalitarianism, utilitarianism offers no specific reason to compensate the costs of mitigation, adaptation and climate damage. Regarding the compensation of adaptation and climate damage costs, utilitarianism attaches no meaning 
to corrective justice as an end in itself. On the contrary, fully compensating victims for damage may reduce the incentive to adapt to climate change in a cost-effective way. However, in as far as mitigation, adaptation and damage costs are to be shared, utilitarianism would recommend the wealthier countries footing the bill according to the ability to pay principle. In this respect, utilitarianism is therefore largely consistent with liberal egalitarianism (see also [98]).

\section{Ethics in the UNFCCC}

This section does not aim to provide a detailed history or overview of the climate negotiations, but rather to illustrate how the aforementioned distributive principles related to right- and left-libertarianism, (cosmopolitan) liberal egalitarianism and utilitarianism can all be identified in the actual climate negotiations, most exemplarily and explicitly in the formulation of the UNFCCC and the response of the United States. The 1992 UNFCCC did not only establish the common goal of preventing dangerous anthropogenic interference with the climate system, but also included rudimentary moral guidelines known as the principle of common but differentiated responsibilities (CBDR). The UNFCCC noted "that the largest share of historical and current global emissions of greenhouse gases has originated in developed countries, that per capita emissions in developing countries are still relatively low and that the share of global emissions originating in developing countries will grow to meet their social and development needs". It was therefore concluded that "The Parties should protect the climate system for the benefit of present and future generations of humankind, on the basis of equity and in accordance with their common but differentiated responsibilities and respective capabilities." The CBDR is also included in Principle 7 of the 1992 Rio Declaration: developed countries bear a greater responsibility "in view of the pressures their societies place on the global environment and of the technologies and financial resources they command" [99]. Both the UNFCCC and the Rio Declaration therefore conclude that the developed country Parties should take the lead in environmental protection. As a result, in 1997 many industrialized countries signed the Kyoto Protocol requiring them to reduce their greenhouse gas emissions by on average $5.2 \%$ in $2008-2012$ relative to 1990, but not requiring developing countries to make commitments. Presently, the principle of CBDR also plays a prominent role in the INDCs of developing countries such as India, which demands an equitable share of the carbon budget and financial support from developed countries for their mitigation efforts [4].

Although the CBDR does not spell out what 'equity' or 'taking the lead' implies, it clearly expresses both left-libertarian and liberal-egalitarian/utilitarian ideas. Leftlibertarianism is reflected in the considerations that the greater one's historical emissions the greater one's responsibility to bear the burdens of emission reduction in the present, and that present responsibilities are related to per capita emissions. Liberal-egalitarianism and utilitarianism are reflected in the consideration that a lower level of development justifies a larger claim on resources and that a larger command of technologies and financial resources bring with them a greater responsibility to bear the costs of mitigation.

Despite this apparent unanimity about the principle of CBDR, already when the Rio Declaration was drafted, the Government of the United States of America submitted the following written statement [100]: “The United States does not accept any interpretation of principle/7 that would imply a recognition or acceptance by the United States of any international obligations or liabilities, or any diminution in the responsibilities of developing countries." Consistent with this position, the United States rejected the Kyoto Protocol. Since then, the United States has consistently demanded substantial reduction efforts by developing countries, moreover, and has been reluctant about providing substantial financial support to developing countries [101] (pp. 34-59). The negotiation position of the United States has therefore been strongly skewed towards a right-libertarian approach. 


\section{Discussion and Conclusions}

The target of the Paris Agreement to keep global average temperature increase to well below $2{ }^{\circ} \mathrm{C}$ above pre-industrial levels raises four issues of distributive justice: how to allocate the total amount of greenhouse gases that still can be emitted (carbon budget), who should bear the costs of mitigation, who should bear the costs of adaptation to unavoidable climate change, and who should bear the costs of residual climate damage. In this article it has been shown that the fairness principles coming to the fore in the climate debate can all be related to three theories of distributive justice. These include the principle of grandfathering, which is often omitted from inventories of fairness principles. Table 1 summarizes the relationship between the four issues, the fairness principles and the different theories of distributive justice.

Table 1. Relationship between different theories of distributive justice and principles for the distribution of the carbon budget, mitigation costs, adaptation costs and climate damage.

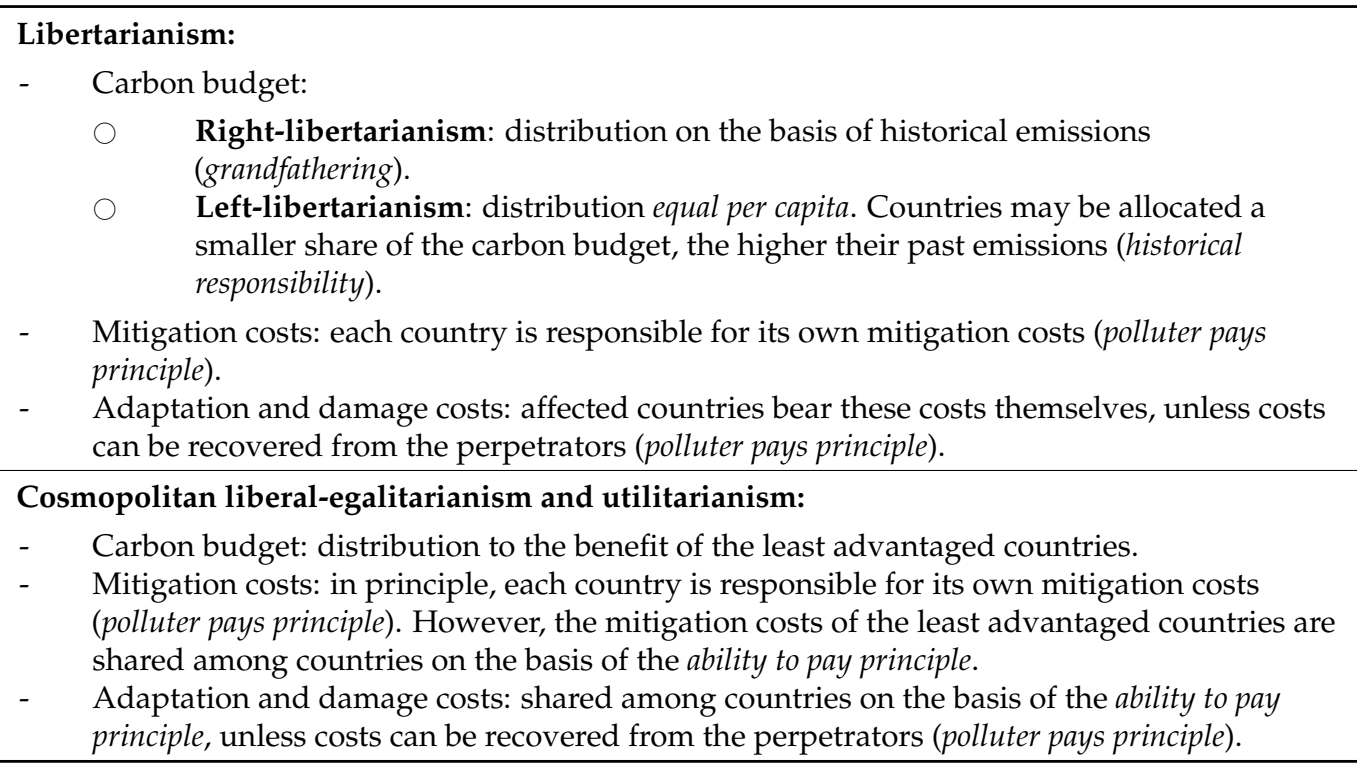

All the theories of distributive justice recommend using flexible economic instruments like tradable emission rights and carbon taxes. In all cases, a globally uniform price for greenhouse gas emissions is established and therefore cost-effectiveness achieved, which is sometimes cited as a separate distributional principle [19]. In the case of libertarianism, cost-effectiveness is not a goal in itself, but a side-effect of voluntary exchange. In the case of liberal-egalitarianism and utilitarianism, it is an intended effect to improve the position of the least advantaged and overall wellbeing, respectively.

The analysis shows that not all fairness principles are 'compatible'. It has been shown, for example, that applying the principle of equal per capita rights to carbon budget allocation is in line with the political theory of left-libertarianism but not cosmopolitan liberal egalitarianism. Where distributing the burdens of mitigation is concerned, however, left-libertarianism is compatible with the polluter pays principle but not with the ability to pay principle. The principle of equal per capita rights is not therefore readily compatible with the ability to pay principle. It has been argued, moreover, that in the context of the international climate negotiations cosmopolitan liberal-egalitarianism and utilitarianism have common goals.

Since allocation of the global carbon budget represents by far the largest distributional issue, the main question facing the international climate negotiations is to what extent allocation of the carbon budget is to be based on the principle of grandfathering, shared on an equal per capita basis or designed such as to aid the least-advantaged countries. Self-evidently, industrialized countries may propose grandfathering as a fairness principle 
in the climate negotiations merely out of self-interest, just as developing countries may propose principles like equal per capita rights merely because it is to their benefit. In that case, each country might very well change their preferred fairness principle if the tables were turned. In fact, one and the same country might take different positions on fairness for different natural resources, such as the carbon budget, fossil fuels and ecosystem services, depending on their own particular access to them. If fairness principles are employed in such a strategic manner, they in fact have little to do with fairness. As the analysis in this paper has shown, though, the various fairness principles are related to different theories of distributive justice and thus to underlying fundamental moral values that are not necessarily related to vested interests. Understanding these different underlying values may facilitate bridge-building and movement in negotiation positions.

Funding: This research received no external funding.

Institutional Review Board Statement: Not applicable.

Informed Consent Statement: Not applicable.

Data Availability Statement: Not applicable.

Conflicts of Interest: The author declares no conflict of interest.

\section{References}

1. United Nations. The 2015 Paris Agreement. Available online: https://unfccc.int/sites/default/files/english_paris_agreement. pdf (accessed on 28 June 2021).

2. Pachauri, R.K.; Meyer, L.A. (Eds.) Climate Change 2014: Synthesis Report; Intergovernmental Panel on Climate Change: Geneva, Switzerland, 2014.

3. UNEP. The Emissions Gap Report 2020; United Nations Environment Programme (UNEP): Nairobi, Kenya, 2020.

4. UNFCCC. UNFCCC Intended Nationally Determined Contributions (INDCs). 2015. Available online: http://www4.un-fccc.int/ submissions/indc/Submission\%20Pages/submissions.aspx (accessed on 28 June 2021).

5. Olson, M. The Logic of Collective Action: Public Goods and the Theory of Groups; Harvard University Press: Cambridge, MA, USA, 1965.

6. Rogelj, J.; Elzen, M.D.; Höhne, N.; Fransen, T.; Fekete, H.; Winkler, H.; Schaeffer, R.; Sha, F.; Riahi, K.; Meinshausen, M. Paris Agreement climate proposals need a boost to keep warming well below $2{ }^{\circ} \mathrm{C}$. Nature 2016, 534, 631-639. [CrossRef]

7. Hardin, G. The tragedy of the commons. Science 1968, 162, 1243-1248.

8. Barrett, S. Climate treaties and the imperative of enforcement. Oxf. Rev. Econ. Policy 2008, 24, 239-258. [CrossRef]

9. Ostrom, E. Governing the Commons: The Evolution of Institutions for Collective Action; Cambridge University Press: New York, NY, USA, 1990.

10. Babiker, M.H. Climate change policy, market structure, and carbon leakage. J. Int. Econ. 2005, 65, 421-445. [CrossRef]

11. Stiglitz, J.E.; Stern, N.; Duan, M.; Edenhofer, O.; Giraud, G.; Heal, G.M.; La Rovere, E.L.; Morris, A.; Moyer, E.; Pangestu, M.; et al. Report of the High-Level Commission on Carbon Prices; World Bank: Washington, DC, USA, 2017.

12. Hof, A.F.; Elzen, M.G.D.; Admiraal, A.; Roelfsema, M.; Gernaat, D.E.; van Vuuren, D.P. Global and regional abatement costs of Nationally Determined Contributions (NDCs) and of enhanced action to levels well below $2{ }^{\circ} \mathrm{C}$ and $1.5^{\circ} \mathrm{C}$. Environ. Sci. Policy 2017, 71, 30-40. [CrossRef]

13. Clarke, L.E.; Jiang, K.; Akimoto, K.; Babiker, M.; Blanford, G.J.; Fisher-Vanden, K.; Hourcade, J.C.; Krey, V.; Kriegler, E.; Loschel, A.; et al. Assessing Transformation Pathways. In Climate Change 2014: Mitigation of Climate Change. Contribution of Working Group III to the Fifth Assessment Report of the Intergovernmental Panel on Climate Change (No. PNNL-SA-102686); Pacific Northwest National Lab (PNNL): Richland, WA, USA, 2015.

14. Munich Re. Record Hurricane Season and Major Wildfires-The Natural Disaster Figures for 2020; Media Release 7 January 2021; Munich Re: Munich, Germany, 2021.

15. Nordhaus, W.; Moffat, A. A Survey of Global Impacts of Climate Change: Replication, Survey Methods, and a Statistical Analysis; National Bureau of Economic Research: Cambridge, MA, USA, 2017.

16. Shue, H. Global Environment and International Inequality. Int. Aff. 1999, 75, 531-545. [CrossRef]

17. Müller, B. Varieties of Distributive Justice in Climate Change. Clim. Chang. 2001, 48, 273-288. [CrossRef]

18. Grasso, M. A normative ethical framework in climate change. Clim. Chang. 2007, 81, 223-246. [CrossRef]

19. Höhne, N.; Elzen, M.D.; Escalante, D. Regional GHG reduction targets based on effort sharing: A comparison of studies. Clim. Policy 2013, 14, 122-147. [CrossRef] 
20. Fleurbaey, M.; Kartha, S.; Bolwig, S.; Chee, Y.L.; Chen, Y.; Corbera, E.; Lecocq, F.; Lutz, W.; Muylaert, M.S.; Norgaard, R.B.; et al. Sustainable Development and Equity. In Climate Change 2014: Mitigation of Climate Change. Contribution of Working Group III to the Fifth Assessment Report of the Intergovernmental Panel on Climate Change; Edenhofer, O., Pichs-Madruga, R., Sokona, Y., Minx, J.C., Farahani, E., Kadner, S., Seyboth, K., Adler, A., Baum, I., Brunner, S., et al., Eds.; Cambridge University Press: Cambridge, UK, 2014.

21. Kolstad, C.; Urama, K.; Broome, J.; Bruvoll, A.; Cariño-Olvera, M.; Fullerton, D.; Gollier, C.; Hanemann, W.M.; Hassan, R.; Jotzo, F.; et al. Social, Economic, and Ethical Concepts and Methods. In Climate Change 2014: Mitigation of Climate Change. Contribution of Working Group III to the Fifth Assessment Report of the Intergovernmental Panel on Climate Change; Edenhofer, O., Pichs-Madruga, R., Sokona, Y., Minx, J.C., Farahani, E., Kadner, S., Seyboth, K., Adler, A., Baum, I., Brunner, S., et al., Eds.; Cambridge University Press: Cambridge, UK; New York, NY, USA, 2014; pp. 207-282.

22. McKinnon, C. Climate justice in a carbon budget. Clim. Chang. 2015, 133, 375-384. [CrossRef]

23. Armstrong, C. Justice and Natural Resources: An Egalitarian Theory; Oxford University Press: Oxford, UK, 2017.

24. Blomfield, M. Global Justice, Natural Resources, and Climate Change; Oxford University Press: Oxford, UK, 2019.

25. Kant, I. Grundlegung zur Metaphysik der Sitten; Johann Friedrich Hartknoch: Riga, Latvia, 1785.

26. Locke, J. Second Treatise of Government; Awnsham Churchill: London, UK, 1690.

27. Nozick, R. Anarchy, State, and Utopia; Basic Books: New York, NY, USA, 1974.

28. Berlin, I. Two Concepts of Liberty: An Inaugural Lecture Delivered Before the University of Oxford on 31 October 1958; Clarendon Press: Oxford, UK, 1958.

29. Narveson, J. The Libertarian Idea; Temple University Press: Philadelphia, PA, USA, 1988.

30. Davidson, M.D. Rights to ecosystem services. Environ. Values 2014, 23, 465-483. [CrossRef]

31. Rothbard, M.N. Law, property rights, and air pollution. Cato J. 1982, 2, 55.

32. Feser, E. There is no such thing as an unjust initial acquisition. Soc. Philos. Policy 2005, 22, 56-80. [CrossRef]

33. Mack, E. The Self-Ownership Proviso: A New and Improved Lockean Proviso. Soc. Philos. Policy 1995, 12, 186-218. [CrossRef]

34. Dominiak, Ł. Must Right-Libertarians Embrace Easements by Necessity? Diametros 2019, 16, 34-51. [CrossRef]

35. Steiner, H. An Essay on Rights; Blackwell: Oxford, UK, 1994.

36. Vallentyne, P. Left-Libertarianism-Primer. In Left Libertarianism and Its Critics: The Contemporary Debate; Steiner, H., Ed.; Palgrave: New York, NY, USA, 2000; pp. 1-22.

37. Otsuka, M. Libertarianism without Inequality; Oxford University Press: Oxford, UK, 2003.

38. Caney, S. Justice and the distribution of greenhouse gas emissions1. J. Glob. Ethics 2009, 5, 125-146. [CrossRef]

39. Moellendorf, D. Global Inequality Matters; Springer Science and Business Media LLC: Berlin, Germany, 2009.

40. Meyer, L.H.; Roser, D. Climate justice and historical emissions. Crit. Rev. Int. Soc. Polit. Philos. 2010, 13, 229-253. [CrossRef]

41. Kartha, S.; Athanasiou, T.; Caney, S.; Cripps, E.; Dooley, K.; Dubash, N.K.; Fei, T.; Harris, P.G.; Holz, C.; Lahn, B.; et al. Cascading biases against poorer countries. Nat. Clim. Chang. 2018, 8, 348-349. [CrossRef]

42. Bovens, L. A Lockean Defense of Grandfathering Emission Rights. In The Ethics of Global Climate Change; Arnold, D., Ed.; Cambridge University Press: Cambridge, UK, 2011; pp. 124-144.

43. Nash, J.R.; Revesz, R.L. Grandfathering and Environmental Regulation: The Law and Economics of New Source Review; Northwestern University Law: Chicago, IL, USA, 2007; pp. 1677-1733.

44. Damon, M.; Cole, D.H.; Ostrom, E.; Sterner, T. Grandfathering: Environmental Uses and Impacts. Rev. Environ. Econ. Policy 2019, 13, 23-42. [CrossRef]

45. Larschan, B.; Brennan, B.C. Common Heritage of Mankind Principle in International Law. Columbia J. Transnatl. Law 1982, 21, 305.

46. Grubb, M. Seeking fair weather: Ethics and the international debate on climate change. Int. Aff. 1995, 71, 463-496. [CrossRef]

47. Agarwal, A.; Narain, S. Global Warming in an Unequal World: A Case of Environmental Colonialism; Centre for Science and Environment: New Delhi, India, 1991.

48. Baer, P.; Harte, J.; Haya, B.; Herzog, A.V.; Holdren, J.; Hultman, N.E.; Kammen, D.M.; Norgaard, R.B.; Raymond, L. Equity and greenhouse gas responsibility. Science 2000, 289, 2287. [CrossRef]

49. Jamieson, D. Climate Change and Global Environmental Justice. In Changing the Atmosphere: Expert Knowledge and Global Environmental Governance; Edwards, P., Miller, C., Eds.; MIT Press: Cambridge, MA, USA, 2001; pp. $287-307$.

50. Hayward, T. Human Rights Versus Emissions Rights: Climate Justice and the Equitable Distribution of Ecological Space. Ethic Int. Aff. 2007, 21, 431-450. [CrossRef]

51. Neumayer, E. In defence of historical accountability for greenhouse gas emissions. Ecol. Econ. 2000, 33, 185-192. [CrossRef]

52. Bode, S. Equal emissions per capita over time-a proposal to combine responsibility and equity of rights for post-2012 GHG emission entitlement allocation. Eur. Environ. 2004, 14, 300-316. [CrossRef]

53. Den Elzen, M.G.J.; Schaeffer, M.; Lucas, P.L. Differentiating future commitments on the basis of countries' relative historical responsibility for climate change: Uncertainties in the 'Brazilian Proposal' in the context of a policy implementation. Clim. Change 2005, 71, 277-301. [CrossRef]

54. Perry, S.R. Libertarianism, entitlement, and responsibility. Philos. Public Aff. 1997, 26, 351-396. [CrossRef]

55. Honoré, T. Responsibility and luck. Law Q. Rev. 1988, 104, 530-549.

56. Gosseries, A. Cosmopolitan luck egalitarianism and climate change. Can. J. Philos. 2005, 31, 279-309.

57. Caney, S. Cosmopolitan Justice, Responsibility, and Global Climate Change. Leiden J. Int. Law 2005, 18, 747-775. [CrossRef] 
58. Simms, A. Ecological Debt: Global Warming and the Wealth of Nations; Pluto Press: London, UK, 2009.

59. Smiley, M. Collective Responsibility. In The Stanford Encyclopedia of Philosophy, Summer 2017 ed.; Zalta, E.N., Ed.; Stanford University: Stanford, CA, USA, 2017.

60. Caney, S. Environmental Degradation, Reparations, and the Moral Significance of History. J. Soc. Philos. 2006, 37, 464-482. [CrossRef]

61. Page, E. Climate Change, Justice and Future Generations; Edward Elgar Publishing: Cheltenham, UK, 2006.

62. Page, E. Climatic Justice and The Fair Distribution of Atmospheric Burdens: A Conjunctive Account. Monist 2011, 94, 412-432. [CrossRef]

63. Page, E.A. Give it up for climate change: A defence of the beneficiary pays principle. Int. Theory 2012, 4, 300-330. [CrossRef]

64. Barry, C.; Kirby, R. Scepticism about beneficiary pays: A critique. J. Appl. Philos. 2017, 34, 285-300. [CrossRef]

65. Miller, D. Global justice and climate change: How should responsibilities be distributed? In The Tanner Lectures on Human Values; Peterson, G.B., Ed.; University of Utah Press: Salt Lake City, UT, USA, 2009; pp. 119-156.

66. Sagoff, M. Four Dogmas of Environmental Economics. Environ. Values 1994, 3, 285-310. [CrossRef]

67. Masson-Delmotte, V.; Zhai, P.; Pörtner, H.-O.; Roberts, D.; Skea, J.; Shukla, P.R.; Pirani, A.; Moufouma-Okia, W.; Péan, C.; Pidcock, R.; et al. Global warming of $1.5^{\circ} \mathrm{C}$. In Proceedings of the Intergovernmental Panel on Climate Change; IPCC: Geneva, Switzerland, 2018.

68. Gaines, S.E. The polluter-pays principle: From economic equity to environmental ethos. Tex. Int. Law J. 1991, $26,463$.

69. Ricke, K.L.; Caldeira, K. Maximum warming occurs about one decade after a carbon dioxide emission. Environ. Res. Lett. 2014, 9, 124002. [CrossRef]

70. Joos, F.; Roth, R.S.; Fuglestvedt, J.S.; Peters, G.P.; Enting, I.G.; Von Bloh, W.; Brovkin, V.; Burke, E.J.; Eby, M.; Edwards, N.R.; et al. Carbon dioxide and climate impulse response functions for the computation of greenhouse gas metrics: A multi-model analysis. Atmos. Chem. Phys. Discuss. 2013, 13, 2793-2825. [CrossRef]

71. Rawls, J. A Theory of Justice; Harvard University Press: Cambridge, MA, USA, 1971.

72. Hofstra, H.J. Socialistische Belastingpolitiek; De Arbeiderspers: Amsterdam, The Netherlands, 1946.

73. Murphy, L.; Nagel, T. The Myth of Ownership: Taxes and Justice; Oxford University Press: Oxford, UK, 2002.

74. Dworkin, R. Taking Rights Seriously; Harvard University Press: Cambridge, MA, USA, 1977.

75. Nielsen, K. Radical egalitarian justice: Justice as equality. Soc. Theory Pract. 1979, 5, 209-226. [CrossRef]

76. Rawls, J. The Law of Peoples. Crit. Inq. 1993, 20, 36-68. [CrossRef]

77. Miller, D. National responsibility and global justice. Crit. Rev. Int. Soc. Polit. Philos. 2008, 11, 383-399. [CrossRef]

78. Nagel, T. The Problem of Global Justice. Philos. Public Aff. 2005, 33, 113-147. [CrossRef]

79. Beitz, C.R. Justice and international relations. Philos. Public Aff. 1975, 4, 360-389.

80. Pogge, T.W. An Egalitarian Law of Peoples. Philos. Public Aff. 1994, 23, 195-224. [CrossRef]

81. Pogge, T.W. A Global Resources Dividend. In Ethics of Consumption: The Good Life, Justice, and Global Stewardship; Crocker, D., Linden, T., Eds.; Rowman and Littlefield: New York, NY, USA, 1998; pp. 501-536.

82. Moellendorf, D. Cosmopolitan Justice; Westview: Boulder, CO, USA, 2002.

83. Posner, E.A.; Sunstein, C.R. Climate change justice. Geo. Law J. 2007, 96, 1565. [CrossRef]

84. Frankfurt, H. Equality as a Moral Ideal. Ethics 1987, 98, 21-43. [CrossRef]

85. Frankfurt, H. Distinguished Lecture in Public Affairs: The Moral Irrelevance of Equality. Publ. Aff. Q. 2000, 14, 87-103.

86. Elster, J. Local Justice: How Institutions Allocate Scarce Goods and Necessary Burdens; Russell Sage Foundation: New York, NY, USA, 1992.

87. Beckerman, W.; Pasek, J. Justice, Posterity, and the Environment; Oxford University Press: Oxford, UK, 2001.

88. Bentham, J. An Introduction to the Principles of Morals; Athlone: London, UK, 1789.

89. Von Hayek, F.A. The Road to Serfdom; Routledge and Kegan Paul: London, UK, 1994.

90. Silver, C.K.; Rand, A. Atlas Shrugged. Engl. J. 1978, 67, 85. [CrossRef]

91. Friedman, M. Capitalism and Freedom; University of Chicago Press: Chicago, IL, USA, 1962.

92. Bentham, J. Pannomial Fragments. In The Works of Jeremy Bentham; Bowring, J., Ed.; William Tait: Edinburgh, Scotland, 1843; Volume 3.

93. Parfit, D. Equality or Priority; University of Kansas, Department of Philosophy: Lawrence, KS, USA, 1991.

94. Singer, P. Famine, affluence, and morality. Philos. Public Aff. 1972, 1, 229-243.

95. Singer, P. One World; Yale University Press: New Haven, CT, USA, 2002.

96. Gesang, B. What Climate Policy Can a Utilitarian Justify? J. Agric. Environ. Ethics 2012, 26, 377-392. [CrossRef]

97. Meyer, L.H.; Roser, D. Distributive justice and climate change: The allocation of emission rights. Anal. Krit. 2006, $28,223-249$. [CrossRef]

98. Pressman, M. The Ability to Pay in Tax Law: Clarifying the Concept's Egalitarian and Utilitarian Justifications and the Interactions between the Two. NYUJ Legis. Public Policy 2018, 21, 141.

99. UNCED. Rio Declaration on Environment and Development, United Nations Conference on Environment and Development, U.N. Doc. A/CONF.151/5/Rev. 1; United Nations: New York, NY, USA, 1992. 
100. UNCED. Report of the United Nations Conference on Environment and Development, U.N. Doc. A/CONF.151/26/Rev.1, Vol.II, Chap.III, Para. 16. 1992. Available online: https://www.un.org/esa/documents/ga/conf151/aconf15126-4.htm (accessed on 28 June 2021).

101. Jamieson, D. Reason in a Dark Time; Oxford University Press: Oxford, UK, 2014. 